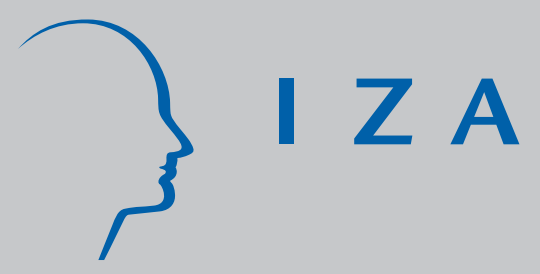

IZA DP No. 3689

Using a Census to Assess the Reliability of a $\mathrm{Na}$ tional Household Survey for Migration Research: The Case of Ireland

Alan Barrett

Elish Kelly

September 2008 


\title{
Using a Census to Assess the Reliability of a National Household Survey for Migration Research: The Case of Ireland
}

\author{
Alan Barrett \\ Economic and Social Research Institute \\ and IZA \\ Elish Kelly \\ Economic and Social Research Institute
}

Discussion Paper No. 3689

September 2008

\author{
IZA \\ P.O. Box 7240 \\ 53072 Bonn \\ Germany \\ Phone: +49-228-3894-0 \\ Fax: +49-228-3894-180 \\ E-mail: iza@iza.org
}

Any opinions expressed here are those of the author(s) and not those of IZA. Research published in this series may include views on policy, but the institute itself takes no institutional policy positions.

The Institute for the Study of Labor (IZA) in Bonn is a local and virtual international research center and a place of communication between science, politics and business. IZA is an independent nonprofit organization supported by Deutsche Post World Net. The center is associated with the University of Bonn and offers a stimulating research environment through its international network, workshops and conferences, data service, project support, research visits and doctoral program. IZA engages in (i) original and internationally competitive research in all fields of labor economics, (ii) development of policy concepts, and (iii) dissemination of research results and concepts to the interested public.

IZA Discussion Papers often represent preliminary work and are circulated to encourage discussion. Citation of such a paper should account for its provisional character. A revised version may be available directly from the author. 


\section{ABSTRACT}

\section{Using a Census to Assess the Reliability of a National Household Survey for Migration Research: The Case of Ireland ${ }^{*}$}

Much research has been conducted on immigration into Ireland in recent years using data from the Quarterly National Household Survey (QNHS), the official source for labour market data in Ireland. As it is known that the QNHS undercounts immigrants in Ireland, a concern exists over whether the profile of immigrants being provided is accurate. For example, QNHS-based research has shown that immigrants in Ireland are a highly educated group. However, if it is the case that those who are missed by the QNHS are more heavily drawn from among low-skilled immigrants, then the profile being reported and used in other research may be inaccurate. In this paper, we use the Irish Census of 2006 to assess the reliability of the profile of immigrants provided by the QNHS by comparing the characteristics of immigrants in both datasets. In general, we find that the QNHS does indeed provide a reliable picture and that earlier findings on the education levels of immigrants in Ireland hold.

JEL Classification: J61

Keywords: migration research, census, household survey, Ireland

Corresponding author:

Alan Barrett

Economic and Social Research Institute

Whitaker Square

Sir John Rogerson's Quay

Dublin 2

Ireland

E-mail: Alan.Barrett@esri.ie

\footnotetext{
* We are grateful to Denis Conniffe, Deirdre Cullen, Seamus McGuinness, Aidan Punch and Philip O'Connell for discussions about aspects of the paper. We would also like to acknowledge the funding provided by the Irish Research Council for the Humanities and Social Sciences under the Government of Ireland Thematic Research Project Grants Scheme.
} 


\section{Section 1: Introduction}

The large inflow of immigrants into Ireland since the mid-1990s has led to the development of a body of research on the topic. Much of this work has focussed on the labour market characteristics of the immigrants (Barrett and Trace, 1998; Barrett et al, 2006). The results of the research on characteristics have, in turn, been used in studies on the labour market impacts, and broader economic impacts, of immigration (Barrett et al, 2002; Barrett et al, 2006).

The studies just referred to have all used the Quarterly National Household Survey (QNHS) $^{2}$ either directly or indirectly in providing insights into the make-up of Ireland's immigrant inflow or in assessing its impact. However, it has been known for some time that the QNHS significantly undercounts the immigrant population, by over 30 percent. Given this undercount, a concern exists that the QNHS may not provide an accurate picture of Ireland's immigrants in terms of socioeconomic characteristics if the undercount is non-random with respect to socioeconomic characteristics. For example, English language skills among immigrants are likely to be positively correlated with education levels. If immigrants with poor English language skills are over-represented among non-respondents in the QNHS, the educational profile of Ireland's immigrant population will be artificially inflated by the QNHS.

In this paper, we will examine the reliability of the QNHS for the purposes of migration research by comparing information on immigrants provided by the survey for the second quarter of 2006 with that provided by the Census of 2006. As the Census is designed and implemented to provide a definitive picture of Ireland's sociodemographic structure, it provides an ideal benchmark against which to assess the reliability of the QNHS. If we were to find significant differences between the pictures provided of Ireland's immigrant population by the Census and the QNHS, much of the earlier work would be open to question. In addition, the future use of the QHNS for migration research would also be questionable. For these reasons, the issue being considered here is of considerable importance. It is also the case internationally

\footnotetext{
${ }^{2}$ The QNHS, which began in 1998, was preceded by the annual Labour Force Survey (LFS). For the purposes of this paper, we will consider the two to be part of the same series of surveys.
} 
that studies of sub-populations are often conducted using surveys which may be representative of the population in general but not of the sub-population in question. Hence, the issue we are addressing has a broader relevance.

The remainder of the paper is structured as follows. In Section 2, we provide a brief overview of the research on immigration in Ireland that has used the QNHS. In Section 3, we move onto our comparison of the information on immigrants that is contained in the QNHS (Q2 2006) and Census 2006. We begin this section by noting differences in the approach to the two surveys and then present descriptive statistics and regression analysis on the characteristics of immigrants from both. In Section 4, we conclude with a discussion of what the comparisons reveal about the reliability of the QNHS for the issue under discussion. In essence, we conclude that the QNHS is indeed reliable and that it will remain a key data source for migration researchers.

\section{Section 2: Migration Research Using the QNHS}

Our focus here is on research which was undertaken in response to the inflow of immigrants into Ireland which began in the mid- to late-1990s. Hence, the first paper of relevance is Barrett and Trace (1998), in which an educational profile of immigrants who arrived between 1994 and 1997 was presented based on pooling the Labour Force Surveys ${ }^{3}$ of those years. The profile showed how immigrants were a remarkably highly-educated group relative to the native population. For example, in the age category 25-29, almost 70 percent of the immigrants had some form of thirdlevel qualification compared with just 32 percent of the native population.

The results in Barrett and Trace (1998) were used by Barrett et al (2002) in estimating the impacts of immigration on wages. Given the highly-skilled nature of the immigrants arriving in the mid-1990s, as indicated by analysis of the QNHS, Barrett et al (2002) simulated the impact of a high-skilled inflow. They showed that such an inflow tended to constrain wage growth at the upper end of the earnings distribution, as high-skilled immigrants competed for jobs with high-skilled natives. However, the

\footnotetext{
${ }^{3}$ See footnote 2 .
} 
high-skilled inflow was positive for wages at the lower end of the distribution because the demand for low-skilled labour increased as a result of the expanding economy.

Barrett et al (2006) updated both Barrett and Trace (1998) and Barrett et al (2002). A profile of immigrants was presented using the QNHS from the second quarter of 2003 along with an estimation of the impacts of immigration, based on the numbers present in Ireland in 2003 and their characteristics. Similar to Barrett and Trace (1998), Barrett et al (2006) found immigrants to be a highly-educated group relative to the native population. However, using regression analysis Barrett et al (2006) also showed that immigrants were not, on average, working in occupations that fully reflected their educational attainment, when compared to native employees. This finding was taken into account when the impacts were estimated, thereby leading to a set of results which included a situation in which the wages of low-skilled native workers fell in response to inward migration.

Barrett and Duffy (forthcoming 2008) also used the QNHS (Q2 2005) to assess whether the length of time immigrants had been resident in Ireland was associated with improved occupational attainment. In this way, they were assessing whether there was evidence of integration into Ireland's labour market. No such evidence was found.

One additional paper which is of relevance is Barrett and McCarthy (2007). Although the QNHS was not used directly in this paper, it was used to assess whether the data being analysed ${ }^{4}$ provided a sample of immigrants which was broadly representative of the immigrant population. Based on comparisons between descriptive statistics from the two surveys, Barrett and McCarthy (2007) argued that their sample was indeed representative of immigrants. They then went on to show large wage disadvantages for immigrants relative to natives and also lower rates of welfare usage.

Another study which used the QNHS for migration research was Russell et al (2008). Their focus here was on experiences of discrimination (on the part of immigrants and others) as opposed to the narrower labour market focus that the previously discussed

\footnotetext{
${ }^{4}$ The data used by Barrett and McCarthy (2007) was the 2004 version of the Irish component of the European Union Survey on Income and Living Conditions (EU-SILC).
} 
studies typically took. While 12 percent of Irish adults reported that they had felt discriminated against, the figure for non-nationals was 24 percent. This research was based on a special module attached to one of the QNHS surveys in 2004, looking specifically at discrimination.

Other research which has been undertaken on Ireland's immigrants has tended to use non-random samples or samples from specific sub-populations ${ }^{5}$. Examples of such work include Ruhs (2005) who looked only at holders of work-permits and so did not include EU nationals. Hence, the bulk of our knowledge on Ireland's immigrant population, and on its impact, has come from work either using the QNHS directly or indirectly. Given the importance of the QNHS in providing this knowledge, we need to be assured that it is reliable when used for migration research.

Section 3: Comparing the Profile of Immigrants from the Census and the QNHS

Our primary purpose in this section is to present comparisons of the profiles of immigrants in Ireland based on the QNHS from Quarter 2 of 2006 and the Census of 2006, the data for which was collected in April 2006. Before doing so, it is useful to provide some brief notes on the methods of data collection employed in both.

The purpose of the QNHS is to provide quarterly labour force estimates. Information is collected throughout the year with 3,000 households surveyed each week, giving a total of 39,000 households each quarter. A two-stage sample design is used. In the first stage 2,600 small areas are selected, where each block contains 75 dwellings on average. In the second stage, 15 dwellings within each block are selected to give a quarterly sample of 39,000 households. Participation in the survey is voluntary.

The purpose of the Census is to count the number of people in the state and to provide details of the socio-demographic characteristics of the population. For 2006, forms were delivered to 1.5 million dwellings; 275,000 dwellings were vacant at the time of the Census. Participation is mandatory. In addition, the Census form was translated into a range of languages specifically for the purpose of ensuring the inclusion of

\footnotetext{
${ }^{5}$ One exception is Minns (2005) who used the Census of 2002 to look at the educational characteristics of immigrants.
} 
immigrants. This is in contrast to the QNHS where information is collected by interviewers, most of whom would not be bi- or multi-lingual. It is this particular feature of the QNHS which leads to a concern that immigrants with poor English language skills may be over-represented among the non-respondents. An additional concern about any survey through which it is hoped that immigrants are sampled is that those illegally in the country are more likely to refuse to participate. Give that the QNHS is voluntary, in contrast to the Census, this particular problem may be more acute in the case of the $\mathrm{QNHS}^{6}$.

The Central Statistics Office makes available micro-data from both the Census and the QNHS. In the case of the Census 2006, a 5 percent random sample is provided. Some of the variables have been omitted from the public file and others have been aggregated, for the purposes of ensuring anonymity. The QNHS data file contains information on all observations but, again, some of the variables are omitted or aggregated. These omissions and aggregations across the two data sources mean that we can only look at a limited set of variables when comparing the profiles of immigrants. These are presented in Table 2 below. We also restrict our attention to labour force participants ${ }^{7}$ as these were the focus of most of the earlier research whose validity we are attempting to assess.

We begin our comparisons by assessing the profiles of immigrants from the QNHS and the Census as presented in Table 1. The figures shown are the calculated proportions of the samples who are immigrants, where immigrants are defined as nonIrish nationals who were not born in Ireland. In addition to presenting figures for all nationalities combined, we also show the proportions of immigrants by broad regional groups: the UK, the “old” EU (meaning the EU-15 prior to May 2004, less Ireland and the UK), the EU New Member States (as of May 2004) and “other” (meaning everyone else except the US which is omitted due to small numbers).

\footnotetext{
${ }^{6}$ In releases such as Central Statistics Office (2008), the CSO make reference to how "the very large migration flows in recent years present a significant measurement challenge in a general purpose household survey such as the QNHS.” They go on to say that "the main concerns, which are based on international experience, centre around the extent to which the survey captures minority communities in a proportionate and representative manner".

${ }^{7}$ By labour force participants we mean people, aged between 15 and 64, who describe themselves as being employed or unemployed but looking for work.
} 
Looking at the first column of numbers, we can see that 12.2 percent of the Census sample (of labour force participants) are immigrants whereas only 7.8 percent of the QNHS sample are immigrants. This suggests that the QNHS undercounts this particular group of immigrants by 36 percent. Based on the calculated z-statistics, we can say that the difference between the proportions is significantly different from zero. Looking within the immigrant group, we find that the undercount applies to all groups. The largest proportionate undercounts are for immigrants from the UK and the EU New Member States, both groups being undercounted by 40 percent. The finding with regard to the UK is something of a surprise. As noted above, our a priori expectation was that immigrants with poor English language skills would have been under-represented in the QNHS but this appears not to be the case, based on the information in Table 1.

We now turn to look at the pictures of immigrants' characteristics that emerge from the Census and the QNHS. As noted above, the omission of some variables places a limit on the set of variables that we can consider. Similarly, the different categorisation of other variables across the two samples in the files that have been provided also makes a number of other variables unusable for comparison purposes. For these reasons, we have restricted our attention to the following variables: gender, age, education and work status (i.e. employed or unemployed, as we are only looking at labour force participants) ${ }^{8}$. For each sample, we have looked at the profiles of immigrants from the four regions (UK, Old EU-13, EU-New Member State and Other) across these four variables. The profiles are presented in Tables 2-5 and we now discuss each in turn.

In Table 2, we look at the UK immigrants. Looking firstly at the gender column, we see that 58 percent of the UK immigrants in the Census are men while the corresponding figure for the QNHS is 59 percent. The z-statistic when testing for a difference between these proportions is only -0.49 , well below the critical value of 1.96, which would signify a significant difference at the 5 percent level. Looking at the columns on age, we again see minor differences between the proportions, with just one of the seven being significant (45-54 years).

\footnotetext{
${ }^{8}$ Ideally, we would also have looked at occupations and sectors of employment but these data are not provided on a consistent basis across the two datasets.
} 
As discussed above, much of the earlier research on immigrants in Ireland based on the QNHS has shown them to have (a) similar rates of unemployment relative to the native population (Barrett and Duffy, forthcoming 2008) and (b) higher rates of education attainment (Barrett et al, 2006). Given the concerns about the representativeness of the QNHS, our Census/QNHS comparisons on these variables are of particular interest. It can be seen in Table 2 that for the UK immigrants, there is no statistically significant difference between the proportions in the Census and the QNHS with regard to employment status. However, we do see some statistically differences when we look at education. While the Census shows that only 4.1 percent of UK immigrants have just primary educations, the QNHS gives a statistically significant higher proportion of 8.3 percent. We also see a statistically significant difference for the Junior Certificate proportions. Given the possibility of misclassification by immigrants of educational qualifications within second-level and third-level categories, we aggregate these in the last two columns. When we do this, we still find a statistically difference between the Census and the QNHS with regard to second-level qualifications. However, there is no such difference with regard to third-level qualifications.

In Table 3, we look at immigrants from the EU's New Member States (NMS). As was the case with the UK immigrants, there are no statistically significant differences between the proportions calculated from the Census and the QNHS with regard to gender. Similarly, there is no difference with regard to age. However, we do find a difference when we look at employment status, with the QNHS suggesting a higher employment rate than the Census.

Looking at education, it appears that the QNHS under-estimates the proportion of NMS immigrants with second-level qualifications and that it over-estimates the proportion with only primary education. There is no difference between the two samples with regard to third-level qualifications, once our re-categorisation is employed.

The over-estimating of immigrants from the NMS with primary educations in the QHNS was counter to our a priori expectations. As our primary concern about the reliability of the QNHS related to the possible omission of immigrants with poor 
English language skills, we had expected that the QNHS would under-estimate those with low levels of education. According to Table 3, however, this is not the case for immigrants from the NMS.

In Table 4, we present the calculations for immigrants from the old EU, meaning the 15 members prior to May 2004, less Ireland and the UK. The degree of similarity between the two samples is closer than it was in the case of both the UK and the NMS. There are only two statistically significant differences in proportions across the two samples, one within the age category and one within the educational categories. The QNHS provides an over-estimate of those with third-level non degree qualifications. We noted above that there is a possibility of misclassification within the broad third-level category and for this reason we aggregated into a single category. When we do so, there is no statistically significant difference between the proportions in the Census and the QNHS.

Our final group to be analysed on the basis on these variables are immigrants from “other” states, meaning all immigrants apart from those considered in Tables 2-4 and immigrants from the US. Immigrants from the US are identified within the data but there number is small. In Table 5, we present the same proportions and z-statistics for these immigrants as was presented in Tables 2-4. The picture that emerges is one of relatively few statistically significant differences. We can see that the proportion of 35-44 year olds is higher, statistically, in the QNHS relative to the Census. It is also the case that the employment rate in the QNHS is higher, again statistically. The QNHS shows a lower proportion of other-state immigrants with Junior Certificate level qualifications. However, once the aggregated category “all second-level” is used, this difference is no longer present. As with all other three regional groupings, there is no statistically significant difference between the proportions reported as having third-level qualifications.

We have now presented the details of the profiles of immigrants from the Census and the QNHS and it seems reasonable to conclude that the differences are few, especially when three educational categories are used as opposed to five. Where differences arise, such as the over-estimate by the QNHS of the proportion of NMS immigrants in 
primary education, they do not point to the under-representation of lower-skilled immigrants in the QNHS.

As a further line of investigation into the reliability of the QNHS, we ran identical regressions using the QNHS and the Census so that we could assess whether there were significant differences between the coefficient estimates. In particular, for both the QNHS and the Census, we selected the natives in the labour forces along with the immigrants and ran probit regressions in which the dependent variable was equal to 1 if the person was unemployed and zero otherwise. The independent variables included gender, age, education, marital status and region of residence within Ireland, plus a set of dummy variables indicating that an individual was an immigrant from one of the four regions discussed above. Given this set up, the interpretation of the estimated marginal effects associated with these immigrant dummy variables is an immigrant's probability of being unemployed relative to a native.

The results from this probit regression are presented in Table 6. Looking firstly at the results from the regression using the Census, we can see that immigrants from all areas are more likely to be unemployed relative to the native labour force participants and all of the estimated marginal effects are significant. What is of more interest for our purpose here is to see if the marginal effects estimated using the QNHS are the same as those estimated using the Census. As can be seen from Table 6, the zstatistics for the difference between the estimated marginal effects show statistically significant differences in two cases but not in the other two. In the case of immigrants from “other” countries, both the Census and the QNHS show higher likelihoods of being unemployed so both data sets are providing the same broad finding, even if the point estimates differ. For the immigrants from the NMS, the small positive effect from the Census data set essentially becomes zero. While clearly it would be preferable to have achieved the same results across the two data sets, the pattern of results in Table 6 does not suggest that radically different outcomes emerge.

Before concluding, it is useful to note two other avenues of analysis that were conducted. First, analyses in papers such as Barrett and Duffy (forthcoming 2008) have looked at immigrants in the QNHS by year of arrival in an effort to see how the experiences of immigrants differ by length of residence. One obvious extension of the 
analysis presented above was to assess how well the QNHS performed in terms of providing reliable information on immigrants when selected by year of arrival.

The Census did include a question which could, in principle, be used to classify immigrants by year of arrival. However, the non-response rate among immigrants was in the order of 40 percent $^{9}$. This meant that the Census lost its key characteristics of providing a definitive picture of the immigrant population when we looked at immigrants by year of arrival. We did conduct the same analysis as that presented above, looking only at immigrants who arrived between 2001 and 2005. The results ${ }^{10}$ indicated an even greater degree of similarity between the Census and QHNS than for all immigrants. However, interpreting this is not clear-cut given the high degree of non-response to the year of arrival question in the Census ${ }^{11}$.

Our second additional avenue of analysis was to look at the issue again but this time using the weighted data from the QNHS. Grossing factors are available within the QNHS data file which allow for the sample to be reweighted, thereby providing a better reflection of population-level aggregates. The results turned out to be very similar to those in the Tables 1-6. To an extent, this was unsurprising because the reweighting is done with reference to age, gender and region and not with reference to immigrant status.

\section{Section 4: Conclusion}

Starting with Barrett and Trace (1998), a series of papers have emerged on immigration into Ireland. Many of these papers have used data from the Quarterly National Household Survey and have proceeded with an implicit assumption that the data provide a representative sample of immigrants in Ireland. The picture that emerged of immigrants in Ireland was extremely positive, in the sense that the

\footnotetext{
${ }^{9}$ The precise question is worded as follows. Respondents are firstly asked "Have you lived outside the Republic of Ireland for more than one year?". If the answer is “yes” respondents are then asked to write down the year in which they last took up residence in Ireland. The 40 percent non-response among immigrants arises partly from immigrants answering "no" to the first part of the question and partly from not filling in a year in relation to the second part.

${ }^{10}$ Not shown but available on request.

${ }^{11}$ The non-response rate among immigrants to the equivalent question in the QNHS was less than 1 percent. This difference in response rates could be the result of the Census being self-administered and the QNHS being interviewer-based.
} 
immigrant population appeared to be highly-skilled relative to the native work-force. The impacts of immigration were then estimated based on this positive skill profile.

As noted at the outset, there was reason to question the implicit assumption that the QNHS provided a representative sample of immigrants in Ireland. As it was known that the QNHS undercounted immigrants, the possibility of non-representativeness was present. In addition, as the QNHS was only administered in English, there was the additional possibility of low-skilled immigrants being disproportionally omitted from the QNHS. If this was the case, then the positive picture emerging from analyses of the QNHS may have been false.

In our analysis presented above, we have exploited the opportunity offered by the Census 2006 to assess the reliability of the QNHS data on immigrants. By comparing descriptive statistics, we have been able to show that the pictures provided by the QNHS of the characteristics of immigrants within the national groupings are broadly in line with those provided by the Census. In particular, the highly-educated nature of Ireland's immigrant labour force, relative to the native labour force is confirmed ${ }^{12}$. Where there have been discrepancies, they actually point to the QNHS overestimating the proportion of lower-skilled immigrants and so work using the QHNS may have slightly under-estimated the full human capital contribution of immigration to the Irish economy. We should note again that the QNHS did show significant differences in the extent of undercounts of immigrants across national groupings. Also, the results from our probit analyses were not entirely consistent with a hypothesis of "no difference" between the Census and the QNHS. However, with regard to the probit analysis, it could not be said that the QNHS provided a qualitatively different picture of immigrants, relative to the Census.

These are important findings and not just by way of providing support for earlier results. There remain many unexplored areas with regard to immigrants in Ireland. As the QNHS offers one of the few large-scale surveys of immigrants, it will remain a crucial input into immigration research in Ireland. This applies to both the standard

\footnotetext{
${ }^{12}$ The Census data show that about 35 percent of the native labour force has third-level qualifications. With the exception of immigrants from the NMS, the corresponding proportions for Ireland immigrants are much higher, as shown in Tables 2, 4 and 5.
} 
information collected in each survey but also to the special modules that are regularly run on particular topics. 
Tables

Table 1: Immigrants as a Proportion of the Census and QNHS Samples

\begin{tabular}{|c|c|c|c|c|c|}
\hline & Immigrant & UK & EU13 & NMS & Other \\
\hline Census & $\begin{array}{c}0.122 \\
(10,211)\end{array}$ & $\begin{array}{c}0.032 \\
(2,681)\end{array}$ & $\begin{array}{c}0.013 \\
(1,129)\end{array}$ & $\begin{array}{c}0.045 \\
(3,777)\end{array}$ & $\begin{array}{c}0.029 \\
(2,452)\end{array}$ \\
\hline QNHS & $\begin{array}{c}0.078 \\
(2,805)\end{array}$ & $\begin{array}{l}0.019 \\
(686)\end{array}$ & $\begin{array}{l}0.011 \\
(403)\end{array}$ & $\begin{array}{l}0.027 \\
(973)\end{array}$ & $\begin{array}{l}0.020 \\
(703)\end{array}$ \\
\hline Z stat & 22.53 & 12.42 & 3.22 & 14.68 & 9.75 \\
\hline $\begin{array}{l}\text { \% Undercount in } \\
\text { QNHS }\end{array}$ & 0.36 & 0.40 & 0.17 & 0.40 & 0.34 \\
\hline
\end{tabular}

Note: Numbers in brackets refer to the actual numbers of immigrants in the samples. The sample size for the Census (natives plus immigrants) is 83,704; for the QNHS it is 35,962. Z refers to the statistic calculated to test for the difference between the proportions. The same applies for Tables 2-5.

Table 2: Profiles of UK Immigrants from the Census 2006 and the QNHS (Q2 2006)

\begin{tabular}{|c|c|c|c|c|c|c|c|}
\hline & $\begin{array}{r}\text { Gender } \\
\text { Male } \\
\end{array}$ & & & $\begin{array}{r}\text { Work Stat } \\
\text { Employe }\end{array}$ & & & \\
\hline Census & 0.580 & & & 0.894 & & & \\
\hline QNHS & 0.590 & & & 0.898 & & & \\
\hline \multirow[t]{3}{*}{$\mathbf{z}$} & -0.491 & & & -0.324 & & & \\
\hline & \multicolumn{7}{|c|}{ Age } \\
\hline & $15-19$ & $20-24$ & 25-34 & $35-44$ & $45-54$ & $55-59$ & $60-64$ \\
\hline Census & 0.017 & 0.058 & 0.236 & 0.347 & 0.214 & 0.079 & 0.048 \\
\hline QNHS & 0.019 & 0.041 & 0.203 & 0.343 & 0.255 & 0.092 & 0.048 \\
\hline \multirow[t]{3}{*}{$\mathbf{z}$} & -0.389 & 1.752 & 1.881 & 0.212 & -2.282 & -1.089 & 0.042 \\
\hline & \multicolumn{7}{|c|}{ Education } \\
\hline & Primary & $\begin{array}{l}\text { Junior } \\
\text { Cert }\end{array}$ & $\begin{array}{l}\text { Leaving } \\
\text { Cert }\end{array}$ & $\begin{array}{l}\text { Third-level } \\
\text { non degree }\end{array}$ & $\begin{array}{l}\text { Third-level } \\
\text { degree }\end{array}$ & $\begin{array}{l}\text { All Second- } \\
\text { level }\end{array}$ & $\begin{array}{l}\text { All Third- } \\
\text { level }\end{array}$ \\
\hline Census & 0.041 & 0.238 & 0.305 & 0.137 & 0.279 & 0.543 & 0.416 \\
\hline QNHS & 0.083 & 0.198 & 0.276 & 0.160 & 0.283 & 0.474 & 0.443 \\
\hline $\mathbf{z}$ & -4.581 & 2.226 & 1.511 & -1.599 & -0.178 & 3.263 & -1.290 \\
\hline
\end{tabular}


Table 3: Profiles of EU New Member State Immigrants from the Census 2006 and the QNHS (Q2 2006)

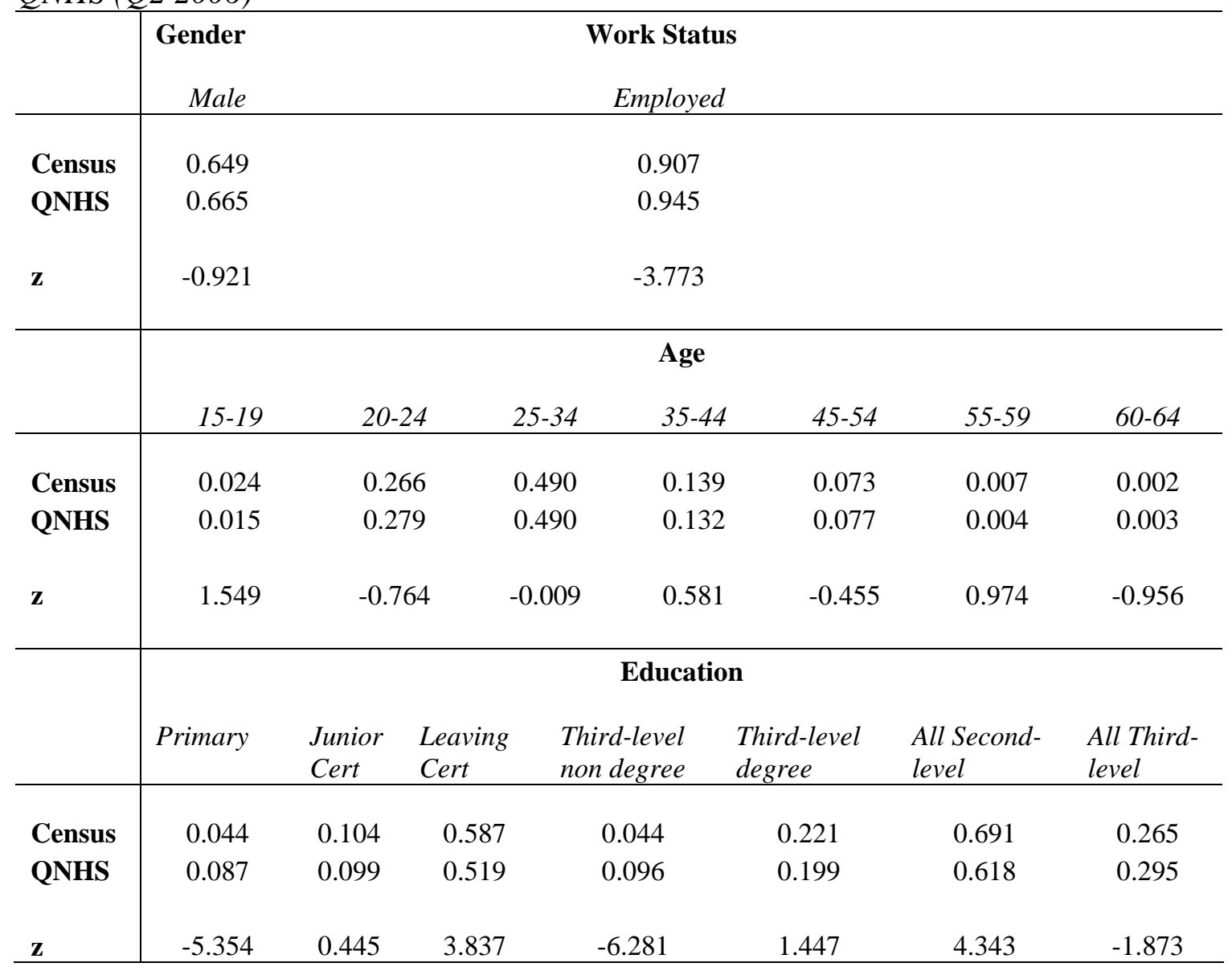


Table 4: Profiles of Old EU Immigrants from the Census 2006 and the QNHS (Q2 2006)

\begin{tabular}{|c|c|c|c|c|c|c|c|}
\hline & $\begin{array}{r}\text { Gender } \\
\text { Male } \\
\end{array}$ & & & $\begin{array}{c}\text { Work Stat } \\
\text { Employec }\end{array}$ & & & \\
\hline Census & 0.507 & & & 0.931 & & & \\
\hline QNHS & 0.529 & & & 0.950 & & & \\
\hline \multirow[t]{3}{*}{$\mathbf{z}$} & -0.755 & & & -1.371 & & & \\
\hline & \multicolumn{7}{|c|}{ Age } \\
\hline & $15-19$ & $20-24$ & $25-34$ & $35-44$ & $45-54$ & $55-59$ & $60-64$ \\
\hline Census & 0.010 & 0.108 & 0.501 & 0.229 & 0.107 & 0.030 & 0.015 \\
\hline QNHS & 0.012 & 0.141 & 0.444 & 0.231 & 0.129 & 0.032 & 0.010 \\
\hline \multirow[t]{3}{*}{$\mathbf{z}$} & -0.452 & -1.791 & 1.971 & -0.092 & -1.190 & -0.214 & 0.761 \\
\hline & \multicolumn{7}{|c|}{ Education } \\
\hline & Primary & $\begin{array}{l}\text { Junior } \\
\text { Cert }\end{array}$ & $\begin{array}{l}\text { Leaving } \\
\text { Cert }\end{array}$ & $\begin{array}{l}\text { Third-level } \\
\text { non degree }\end{array}$ & $\begin{array}{l}\text { Third-level } \\
\text { degree }\end{array}$ & $\begin{array}{l}\text { All Second - } \\
\text { level }\end{array}$ & $\begin{array}{l}\text { All Third- } \\
\text { level }\end{array}$ \\
\hline Census & 0.028 & 0.052 & 0.254 & 0.117 & 0.548 & 0.306 & 0.665 \\
\hline QNHS & 0.017 & 0.035 & 0.275 & 0.161 & 0.511 & 0.310 & 0.672 \\
\hline $\mathbf{z}$ & 1.201 & 1.417 & -0.834 & -2.284 & 1.283 & -0.138 & -0.266 \\
\hline
\end{tabular}


Table 5: Profiles of Other Immigrants from the Census 2006 and the QNHS (Q2 2006)

\begin{tabular}{|c|c|c|c|c|c|c|c|}
\hline & $\begin{array}{r}\text { Gender } \\
\text { Male }\end{array}$ & & & $\begin{array}{c}\text { Work Statu } \\
\text { Employed }\end{array}$ & & & \\
\hline Census & 0.584 & & & 0.832 & & & \\
\hline QNHS & 0.602 & & & 0.895 & & & \\
\hline \multirow[t]{3}{*}{$\mathbf{z}$} & -0.857 & & & -4.050 & & & \\
\hline & \multicolumn{7}{|c|}{ Age } \\
\hline & $15-19$ & 20-24 & 25-34 & $35-44$ & $45-54$ & $55-59$ & $60-64$ \\
\hline Census & 0.010 & 0.096 & 0.487 & 0.290 & 0.093 & 0.015 & 0.009 \\
\hline QNHS & 0.006 & 0.090 & 0.451 & 0.347 & 0.084 & 0.020 & 0.003 \\
\hline \multirow[t]{3}{*}{$\mathbf{z}$} & 1.096 & 0.499 & 1.689 & -2.884 & 0.707 & -0.824 & 1.565 \\
\hline & \multicolumn{7}{|c|}{ Education } \\
\hline & Primary & $\begin{array}{l}\text { Junior } \\
\text { Cert }\end{array}$ & $\begin{array}{l}\text { Leaving } \\
\text { Cert }\end{array}$ & $\begin{array}{l}\text { Third-level } \\
\text { non degree }\end{array}$ & $\begin{array}{l}\text { Third-level } \\
\text { degree }\end{array}$ & $\begin{array}{l}\text { All Second- } \\
\text { level }\end{array}$ & $\begin{array}{l}\text { All Third- } \\
\text { level }\end{array}$ \\
\hline Census & 0.054 & 0.098 & 0.263 & 0.126 & 0.459 & 0.361 & 0.585 \\
\hline QNHS & 0.053 & 0.064 & 0.289 & 0.149 & 0.445 & 0.353 & 0.595 \\
\hline $\mathbf{z}$ & 0.102 & 2.792 & -1.370 & -1.595 & 0.645 & 0.317 & -0.320 \\
\hline
\end{tabular}

Table 6: Probit Results (Marginal Effects, Dependent Variable $=1$ if unemployed, 0 if employed)

\begin{tabular}{l|ccccc} 
& Census & \multicolumn{3}{c}{ QNHS } & \multicolumn{2}{c}{$\begin{array}{l}\text { z-stat for difference between } \\
\text { dy/dx's }\end{array}$} \\
& dy/dx & s.e. & dy/dx & s.e. & -0.97 \\
UK & 0.049 & 0.006 & 0.062 & 0.012 & 3.16 \\
NMS & 0.021 & 0.005 & -0.002 & 0.006 & 0.78 \\
EU-13 & 0.027 & 0.012 & 0.014 & 0.012 & 3.70 \\
Other & 0.156 & 0.009 & 0.094 & 0.014 & \\
N & 83,704 & & 35,962 & & \\
LR chi2 & 5263.65 & & 1621.85 & & \\
(21) & & & 0 & & \\
Prob $>$ & 0 & & 0.105 & & \\
chi2 & 0.1134 & & & & \\
Pseudo R2 & & & & & \\
\hline
\end{tabular}




\section{References}

Barrett, A. and D. Duffy, (forthcoming 2008), “Are Ireland's Immigrants Integrating into its Labour Market?”, International Migration Review Vol. 42 No. 3

Barrett, A. and Y. McCarthy (2007), "Immigrants in a Booming Economy: Analysing their Earnings and Welfare Dependence”, Labour: Review of Labour Economics and Industrial Relations Vol. 21 No. 4-5

Barrett, A., A. Bergin and D. Duffy (2006), "The Labour Market Characteristics and Labour Market Impacts of Immigrants in Ireland”, Economic and Social Review Vol. 37 pp. $1-26$

Barrett, A., J. FitzGerald and B. Nolan (2002), “Earning Inequality, Returns to Education and Immigration into Ireland”, Labour Economics Vol. 9 No. 5.

Barrett, A. and F. Trace (1998), "Who is Coming Back? The Educational Profile of Returning Migrants in the 1990s”, Irish Banking Review, Summer pp. 38-52

Central Statistics Office (2008), Quarterly National Household Survey Quarter 2 2008, Dublin: Central Statistics Office.

Minns, C. (2005), "How Skilled Are Irish Immigrants? Evidence and Implications”, paper delivered to the Statistical and Social Inquiry Society of Ireland, 24 February.

Ruhs, M. (2005), Managing the Immigration and Employment of non-EU Nationals in Ireland, Paper No. 19, The Policy Institute, TCD

Russell, H., E. Quinn, R. King-O’Riain, F. McGinnity (2008), The Experience of Discrimination in Ireland: Analysis of the QNHS Equality Module, ESRI Research Series Number 3, Dublin: ESRI and The Equality Authority 